\title{
Erciyes Üniversitesi Öğrencilerinin Süt Tüketim Alışkanlıklarının Belirlenmesi Üzerine Bir Araştırma
}

\author{
Gül PARA ${ }^{1}$, İsmail ÜLGER ${ }^{1}$, Mahmut KALİBER ${ }^{1}$
}

ÖZET: Bu araştırmada, Erciyes Üniversitesinde eğitim gören öğrencilerin süt tüketim alışkanlıkları araştırılmıştır. Çalışmada kullanılan veriler, toplam 240 öğrenci ile yüz yüze görüşme tekniği kullanılarak uygulanan anketler vasıtasıyla elde edilmiştir. Katılımcıların yaş ortalaması 21.4 olarak belirlenmiştir. Katılımcıların \%35'ini sosyal bilimler, \%34'ünü sağlık bilimleri ve \%31'ini ise fen bilimleri branşında eğitim gören öğrenciler oluşturmuştur. Katılımcıların \% 75'i günlük 100-250 ml süt tükettiklerini belirtmişlerdir. Ankete katılan öğrenciler, süt tüketiminin teşviki amacıyla kamu ve sivil toplum kuruluşları tarafından yapılan bilinçlendirme çalışmalarını yetersiz bulduğunu ve bu amaçla kullanılabilecek en etkili yöntemin görsel-işitsel medya olabileceğini belirtmişlerdir.

Anahtar Kelimeler: Anket, beslenme, süt, tüketim, tüketici tercihleri.

\section{A Research on the Determination of the Consumption Habits of Milk among the Students in Erciyes University}

\begin{abstract}
In this study, the habits of milk consumption of undergraduate students of Erciyes University were investigated. The data used in this study was obtained from surveys that carried out on 240 students educated at the Erciyes University with face-to-face interview technique. The average age of participants was determined as 21.4 . While, $35 \%$ of the participant students were studying at social sciences, $34 \%$ were studying at the health sciences and $31 \%$ were studying at the natural and applied sciences. $75 \%$ of the participants stated that they consume 100 $250 \mathrm{ml}$ milk per day. Students also reported that, inciting programs which performed by state or non-governmental organizations are not enough to increase of consumption of milk and audio-visual media can be the most effective method for this purpose.
\end{abstract}

Keywords: Survey, nutrition, milk, consumption, consumer preferences.

Gül PARA (0000-0001-9332-6517), İsmail ÜLGER (0000-0003-3606-0737), Mahmut KALİBER (0000-0001-5572-6384),

Erciyes Üniversitesi, Ziraat Fakültesi, Zootekni Bölümü, Kayseri, Türkiye

Sorumlu yazar/Corresponding Author: Gül PARA, para.gul54@gmail.com 


\section{GíRiş}

Beslenme, insanın büyümesi ve gelişmesi, sağlıklı ve üretken olarak uzun süre yaşaması için gerekli olan enerji ve besin öğelerini (karbonhidrat, protein, yağ, vitamin ve mineralleri) ihtiyaç duyulan miktarda gün içerisinde düzenli olarak alınmasıdır. Belirlenen besin öğesi gereksinimlerin karşılanmasında, süt en önemli besin gruplarının başında gelmektedir. Süt protein, vitaminler ve kalsiyum olmak üzere mineraller gibi beslenmede çok önemli olan besin öğelerini bünyesinde taşımaktadır (Altun ve ark., 2002).

Yeterli ve dengeli beslenme için bir insanın günde alması gereken protein miktarı; kilogram başına 1 gramdır. Protein ihtiyacının minimum üçte biri, hayvansal gıdalardan sağlanmalıdır. $\mathrm{Bu}$ ise günlük ortalama 35 gram hayvansal kaynaklı protein tüketilmesi demektir. Bunun için; süt, yumurta, beyaz et ve kırmızı etin günlük olarak düzenli şekilde tüketilmesi önemlidir (Ayar ve Sert, 2005).

Üniversite öğrencileri erişkin döneme geçme aşamasında olan çocukluk çağı sonrası ilk gruptur. Bu öğrencilerin üniversite eğitiminin başlaması ile birlikte o zamana kadar alıştıkları aile ortamları içerisinden ayrılmaları, dış etkilere daha açık hale gelmeleri ve kendi özgür seçimlerini daha belirgin şekilde yapmaya başlıyor olmaları nedeniyle beslenmelerinde yeni bir dönem başlamaktadır. Bu dönemin belirleyici özelliği ekonomik problemler ve yeni kurulacak bir düzene uyum sağlama çabalarıdır. Beslenme alışkanlıklarında ortaya çıkabilecek yeni formlar üniversite öğrenimi sonrasına taşınacaktır (Mazıcıoğlu ve Öztürk, 2003).

Toplumun farklı kesimlerinin süt tüketim alışkanlıklarının belirlenmesi konusunda farklı hedef kitleler üzerinde daha önceden yapılan anket çalışmaları mevcuttur (Selçuk ve ark., 2003; Tarakçı ve ark., 2003; Şimşek ve Açıkgöz, 2011; Onurlubaş ve ark., 2015). $\mathrm{Bu}$ çalışmada ise; süt tüketim alışkanlıkları konusunda tüketici tercihlerinin zamanla değişip değişmediğine dair güncel verilerin elde edilebilmesi ve sütün insan beslenmesindeki önemine binaen ilgili bakanlıklar, kamu kurum ve kuruluşları ve sivil toplum örgütleri tarafından yürütülen bilinçlendirme çalışmalarının hedef kitle üzerindeki etkilerinin tespit edilebilmesi amacıyla, Erciyes Üniversitesi’nde öğrenim görmekte olan öğrencilerin süt tüketim alışkanlıkları, tüketim düzeyleri ve tercihlerinin belirlenmesi hedeflenmiştir.

\section{MATERYAL VE YÖNTEM}

Araştırma materyalini, Erciyes Üniversitesi'nde öğrenim görmekte olan öğrencilerden anket yoluyla elde edilmiş veriler oluşturmaktadır. Anket yapılacak olan öğrenci sayısı belirlenirken konu ile ilgili yapılmış olan anket çalışmalarından yararlanılmıştır (Selçuk ve ark., 2003; Tarakçı ve ark., 2003; Şimşek ve Açıkgöz, 2011; Onurlubaş ve ark., 2015). Anket çalışması, araştırmaya gönüllü olan 240 öğrenci ile gerçekleştirilmiştir. Araştırmaya katılan 240 öğrencinin 147'sini bayan öğrenciler, 93'ünü erkek öğrenciler oluşturmuştur. Ankete katılan öğrencilerin eğitim gördükleri branşlar homojen olacak şekilde dikkate alınarak tüm popülasyonu temsil edecek şekilde ayarlanmıştır. Katılımcıların \% 35'i sosyal bilimler, \% 34'ü sağlık bilimleri ve \% 31'i fen bilimlerinde eğitim gören öğrenciler oluşturmuştur. Anketler 2017 yılı Mayıs-Haziran aylarında yapılmıştır.

Anket soruları literatürden yararlanılarak daha önce yapılmış benzer çalışmalardan derlenmiştir. Anket toplam 21 sorudan oluşmaktadır. Anket soruları, öğrencilerin sosyo-demografik özellikleri ve süt tüketim alışkanlıkları ile ilgili sorulardan oluşmuştur. Anketteki soruların bazıları tek cevap seçenekli olurken; bazılarını ise birden fazla cevap seçeneğine sahip sorular oluşturmaktadır. Hazırlanan anketler rastgele seçilen öğrencilerle eğitim gördükleri fakültelerde ve kantinlerinde ön açıklama yapılarak yüz yüze görüsşme tekniği ile soru cevap şeklinde gerçekleştirilmiştir. Elde edilen veriler, Microsoft Office Excel 2013 programı kullanılarak sayılar ve oranlar şeklinde değerlendirilmiştir.

\section{BULGULAR VE TARTIŞMA}

Çalışma verilerine göre, ankete katılan öğrencilerin \%61.3'ünü bayan öğrenciler, \%38.8'inü ise erkek öğrenciler oluşturmaktadır (Çizelge 1). Ankete katılanların yaş ortalaması 21.4'tür. Ankete katılan öğrencilerin eğitim gördükleri branşlara göre dağılımının; \%35.3'ünü sosyal bilimler, \%31.1'ini fen bilimleri ve \% 33.6'sını da sağlık bilimleri oluşturmaktadır. Öğrencilerin ikamet ettikleri yerlere göre dağılımı incelenecek olursa; \%62.7'si ev, $\% 27.4$ 'ü yurt, \%9.5'i ise rezidansta ikamet etmektedir. 
Çizelge 1. Ankete katılan öğrencilerin sosyo-demografik özellikleri

\begin{tabular}{|c|c|c|}
\hline Özellik & Sayı & Oran, \% \\
\hline \multicolumn{3}{|l|}{ Cinsiyet } \\
\hline Erkek & 93 & 38.8 \\
\hline $\mathrm{K} 1 \mathrm{z}$ & 147 & 61.2 \\
\hline Toplam & 240 & 100.0 \\
\hline \multicolumn{3}{|l|}{ Yaş Aralığı } \\
\hline $18-20$ & 101 & 42.1 \\
\hline $21-23$ & 108 & 45.0 \\
\hline $24-26$ & 23 & 9.6 \\
\hline 27 ve üzeri & 8 & 3.3 \\
\hline Toplam & 240 & 100.0 \\
\hline \multicolumn{3}{|l|}{ Eğitim Branşı } \\
\hline Sosyal Bilimler & 84 & 35.0 \\
\hline Fen Bilimleri & 75 & 31.3 \\
\hline Sağlık Bilimleri & 81 & 33.7 \\
\hline Toplam & 240 & 100.0 \\
\hline \multicolumn{3}{|l|}{ İkamet Edilen Yer } \\
\hline Ev & 150 & 62.5 \\
\hline Yurt & 66 & 27.5 \\
\hline Rezidans & 23 & 9.6 \\
\hline Diğer & 1 & 0.4 \\
\hline Toplam & 240 & 100.0 \\
\hline
\end{tabular}

Öğrencilerin Süt Tüketim Alışkanlığı ve Günlük Tükettikleri İçme Sütü Miktarı

Öğrencilerin süt tüketim sıklığı Çizelge 2'de görülmektedir. Kız öğrencilerin \%25.9'u haftada bir kez tükettiklerini, \%19.7'si her gün mutlaka tükettiklerini, $\% 17.7$ 'si hiç tüketmediklerini, \%15.6'sı gün aşırı tükettiklerini, \%13.6's1 ayda bir veya daha seyrek tükettiklerini, $\% 7.5$ 'i on beş günde bir süt tükettiklerini belirtmişlerdir.

Erkek öğrencilerin ise \%30.1'i hiç tüketmediklerini, $\% 20.4$ 'ü haftada bir kez tükettiklerini, \%16.1'i gün aşırı tükettiklerini, \%12.9'u ayda bir veya daha seyrek tükettiklerini, $\% 10.8$ 'i her gün mutlaka tükettiklerini ve $\% 9.7$ 'si on beş günde bir süt tükettiklerini belirtmişlerdir. Kız ve erkek öğrenciler arasında süt tüketimi durumundan farklılık gözlemlenmiş ve kız öğrencilerde süt tüketiminin daha fazla olduğu tespit edilmiştir. Buda kız öğrencilerin süt tüketimine erkek öğrencilere oranla daha fazla önem verdiklerini göstermektedir. 
Çizelge 2. Öğrencilerin süt tüketim sıklığı

\begin{tabular}{lccccccccccccccc}
\hline & \multicolumn{3}{c}{ A } & \multicolumn{2}{c}{ B } & \multicolumn{2}{c}{ C } & & D & & E & & F & Toplam \\
\cline { 2 - 13 } Cinsiyet & Sayı & \% & Sayı & \% & Sayı & \% & Sayı & \% & Sayı & \% & Sayı & \% & Sayı & \% \\
\hline K1z & 29 & 19.7 & 23 & 15.7 & 38 & 25.9 & 11 & 7.5 & 20 & 13.6 & 26 & 17.7 & 147 & 100 \\
Erkek & 10 & 10.8 & 15 & 16.1 & 19 & 20.4 & 9 & 9.7 & 12 & 12.9 & 28 & 30.1 & 93 & 100 \\
Toplam & 39 & 16.3 & 38 & 15.8 & 57 & 23.8 & 20 & 8.3 & 32 & 13.3 & 54 & 22.5 & 240 & 100 \\
\hline
\end{tabular}

A: Her gün mutlaka; B:Gün aşırı; C:Haftada bir kez; D: On beş günde bir; E: Ayda bir veya daha seyrek; F: Hiç tüketmiyorum.

Süt tüketmeyen öğrencilerin sütü tüketmeme nedenleri sorulduğunda ise alınan cevaplar Çizelge 3'de görülmektedir. Öğrencilerin büyük çoğunluğu sütü neden tüketmediğini bilmediğini belirtmişlerdir. $\mathrm{Bu}$ oran $\mathrm{k1z}$ öğrencilerde \%45.7 iken erkek öğrencilerde \%72.2 olarak tespit edilmiştir. Tarakçı ve ark. (2003) yaptıkları çalışmada, kokusundan dolayı süt içmeyenlerin oranının \%23.60, tadından dolayı tüketmeyenlerin oranının \%33.71, alerjik rahatsızlığ 1 olanların oranının \%13.48 ve diğer nedenlerden dolayı tüketmeyenlerin oranının ise \%29.21 olduğunu ifade etmişlerdir. Yapılan iki çalışmadan alınan veriler arasında farklılık gözlemlenmekte ve bizim yaptığımız çalışmada öğrencilerin sütü neden tüketmediklerini bilmedikleri göze çarpmaktadır.

Öğrencilerin beslenme alışkanlığı ile süt tüketimi arasında doğrudan bir ilişki olduğu ve çocukluktan gelen süt tüketim alışkanlığının ilerleyen yaşlarda da devam ettiği bilinmektedir. Süt tüketiminin arttırılması için ailelerle ortak çalışmalar yürütülmeli ve sütün çocukların gelişimi için hayati öneme sahip olduğu vurgulanmalıdır.

Çizelge 3. Öğrencilerin sütü tüketmeme nedenleri

\begin{tabular}{lccccccccccccc}
\hline & \multicolumn{3}{c}{ A } & \multicolumn{2}{c}{ B } & & C & & D & & E & Toplam \\
\cline { 2 - 11 } Cinsiyet & Sayı & $\%$ & Sayı & $\%$ & Sayı & $\%$ & Sayı & \% & Sayı & \% & Sayı & \% \\
\hline Kiz & 9 & 25.7 & 5 & 14.3 & 4 & 11.4 & 1 & 2.9 & 16 & 45.7 & 35 & 100 \\
Erkek & 4 & 11.1 & 2 & 5.6 & 3 & 8.3 & 1 & 2.8 & 26 & 72.2 & 36 & 100 \\
Toplam & 13 & 18.3 & 7 & 9.9 & 7 & 9.9 & 2 & 2.8 & 42 & 59.2 & 71 & 100 \\
\hline
\end{tabular}

A: Tadı; B:Kokusu; C:Rahatsızlık veriyor; D: Alerjik rahatsızlık; E: Diğer.

Ankete katılan öğrencilere sütü hangi öğünlerde tükettikleri sorulduğunda alınan cevaplar ile oranları Çizelge 4'de görülmektedir. Sütü, kız öğrencilerin \%28.6's1 akşam, \%22.2'si sabah, \%22.2'si öğün arasında, \%19.0'1 yatmadan önce, \%7.9'u öğlen tükettiklerini belirtirken; erkek öğrencilerin \%41.5'i akşam, \%18.5'i sabah, \%16.9'u yatmadan önce, $\% 12.3$ 'ü öğün arasında ve \%10.8'i öğlen tükettiklerini belirtmişlerdir. Alınan sonuçlardan öğrencilerin süt tüketiminin düzensiz olduğu görülmektedir. 
Çizelge 4. Öğrencilerin sütü tükettiği öğünler

\begin{tabular}{lcccccccccccc}
\hline & \multicolumn{3}{c}{ A } & \multicolumn{2}{c}{ B } & \multicolumn{2}{c}{ C } & \multicolumn{2}{c}{ D } & \multicolumn{2}{c}{ E } & \multicolumn{3}{c}{ Toplam } \\
\cline { 2 - 11 } Cinsiyet & Sayı & \% & Sayı & \% & Sayı & \% & Sayı & \% & Sayı & \% & Sayı & \% \\
\hline Kız & 28 & 22.2 & 10 & 7.9 & 36 & 28.6 & 24 & 19.0 & 28 & 22.2 & 126 & 100 \\
Erkek & 12 & 18.5 & 7 & 10.8 & 27 & 41.5 & 11 & 16.9 & 8 & 12.3 & 65 & 100 \\
Toplam & 40 & 20.9 & 17 & 8.9 & 63 & 33.0 & 35 & 18.3 & 36 & 18.9 & 191 & 100 \\
\hline
\end{tabular}

A: Sabah; B: Öğlen; C: Akşam; D: Yatmadan önce; E: Öğün arası.

Öğrencilere günlük tükettiği içme sütü miktarı sorulduğunda alınan cevapların oranı Çizelge 5'de görülmektedir. Öğrencilerin büyük çoğunluğu günlük 100-250 ml arasında süt tükettiklerini bildirmişlerdir. Bu oran kız öğrencilerde \%84.9 iken erkek öğrencilerde
\%61.5 olarak tespit edilmiştir. Elde edilen sonuçlar göz önünde tutularak; insan beslenmesinde çok büyük öneme sahip olan içme sütünün tüketimini arttırmak için çalışmalar düzenlenmeli ve besin değeri hakkında gerekli bilgilendirme çalışmaları yapılmalıdır.

Çizelge 5. Günlük tüketilen içme sütü miktarı

\begin{tabular}{lcccccccccc}
\hline & \multicolumn{2}{c}{$\mathbf{1 0 0 - 2 5 0} \mathbf{~ m l}$} & \multicolumn{2}{c}{$\mathbf{2 5 0 - 5 0 0} \mathbf{~ m l}$} & \multicolumn{2}{c}{$\mathbf{5 0 0} \mathbf{~ m l}$} & \multicolumn{2}{c}{ Hiç } & \multicolumn{2}{c}{ Toplam } \\
\cline { 2 - 11 } Cinsiyet & Sayı & $\mathbf{\%}$ & Sayı & $\mathbf{\%}$ & Sayı & $\mathbf{\%}$ & Sayı & \% & Sayı & \% \\
\hline Kız & 101 & 84.9 & 15 & 12.6 & 3 & 2.5 & 0 & 0 & 119 & 100 \\
Erkek & 40 & 61.5 & 19 & 29.2 & 6 & 9.2 & 0 & 0 & 65 & 100 \\
Toplam & 141 & 76.6 & 34 & 18.5 & 9 & 4.9 & 0 & 0 & 184 & 100 \\
\hline
\end{tabular}

Öğrencilerin Sütü Tercih Etme Nedenleri ve Tercih Ettikleri İ̧̧me Sütü Çeşitleri

Öğrencilere "Sütü neden tercih ediyorsunuz?" sorusu sorulduğunda alınan cevapların oranı Çizelge 6'da görülmektedir.

Kız öğrencilerin \%42.1'i besleyici özelliğinden dolayı tükettiğini, \%28.9'u bir nedeni olmadığını, $\% 24.8$ 'i alışkanlıktan dolayı tükettiğini ve \%4.1'i de rahatsızlığı olduğu için tercih ettiğini belirtirken; erkek öğrencilerin \%46.2'si besleyici özelliğinden dolayı tükettiğini, \%29.2'si bir nedeni olmadığını, $\% 23.1$ 'i alışkanlıktan dolayı tükettiğini ve \%1.5'i rahatsızlı̆̆1 olduğu için tükettiklerini ifade etmişlerdir.

Çetinkaya (2010) yaptığı çalışmada, sütü öğrencilerin \%46'sının besleyici olduğundan,
$\% 25.3$ 'ünün vitamin, kalsiyum ve protein ihtiyacını karşıladığından dolayı tercih ettiklerini bildirmiştir. Kahraman (2016) yaptığı benzer bir çalışmada; katılımcıların içme sütü tüketme nedenlerinin, "katılıyorum" ve "kesinlikle katılıyorum" cevap seçenekleri bir kabul edilerek toplam \%81.9'unun sağlık açısından tükettiğini, \%74.4'ünün süt içmeyi sevdikleri için tükettiklerini ve \%60.6'sının kokusu/ tadı hoşlarına gittiği için tükettiklerini tespit etmiştir.

Gerek bizim yaptığımız çalışma gerekse diğer yapılan çalışmalardan görüldüğü üzere; süt tüketenlerin süt tüketme nedeni olarak "besleyicilik" ve "sağlık" ön plana çıkmaktadır. 
Çizelge 6.Öğrencilerin sütü tercih etme nedenleri

\begin{tabular}{lcccccccccc}
\hline & \multicolumn{2}{c}{ Besleyicilik } & \multicolumn{2}{c}{ Alışkanlık } & \multicolumn{2}{c}{ Rahatsızlı } & \multicolumn{2}{c}{ Hiçbiri } & \multicolumn{2}{c}{ Toplam } \\
\cline { 2 - 12 } Cinsiyet & Sayı & \% & Sayı & \% & Sayı & \% & Sayı & \% & Sayı & \% \\
\hline Kız & 51 & 42.1 & 30 & 24.8 & 5 & 4.1 & 35 & 28.9 & 121 & 100 \\
Erkek & 30 & 46.2 & 15 & 23.1 & 1 & 1.5 & 19 & 29.2 & 65 & 100 \\
Toplam & 81 & 43.6 & 45 & 24.2 & 6 & 3.2 & 54 & 29.0 & 186 & 100 \\
\hline
\end{tabular}

Ankete katılan öğrencilerin tükettikleri içme sütü çeşitleri sorulduğunda alınan cevapların oranı Çizelge 7 'de verilmiştir. Alınan cevaplardan öne çıkan sonuçlar, öğrencilerin sütü en çok soğuk (\%37.6) ve sicak (\%20 .1) olarak tüketmeyi sevdikleri şeklindedir. Tarakçı ve ark. (2003) yılında yaptıkları benzer bir çalışmada; öğrencilerin \%27.42'sinin sütü sıcak olarak tükettiğini ve $\% 22.65$ 'inin şekerli sütü sevdiğini belirtmişlerdir. Yapılan iki çalışmada da alınan sonuçlara bakıldığında öğrencilerin sütü farklı şekilde tüketmeyi sevdikleri görülmektedir.

Çizelge 7. Öğrencilerin tükettikleri değişik özellikteki süt türleri

\begin{tabular}{|c|c|c|c|c|c|c|c|c|c|}
\hline \multirow{2}{*}{ Cinsiyet } & Sicak & Soğuk & Şekerli & Şekersiz & Kakaolu & Meyveli & Kahveli & Diğer & Toplam \\
\hline & \multicolumn{8}{|c|}{ Öğrenci Sayısı } & \\
\hline $\mathrm{K}_{1 \mathrm{Z}}$ & 30 & 53 & 15 & 13 & 27 & 5 & 4 & 2 & 149 \\
\hline Erkek & 16 & 33 & 7 & 10 & 9 & 1 & 2 & 2 & 80 \\
\hline \multirow[t]{2}{*}{ Toplam } & 46 & 86 & 22 & 23 & 36 & 6 & 6 & 4 & 229 \\
\hline & \multicolumn{8}{|c|}{$\%$} & \\
\hline $\mathrm{K} 1 \mathrm{z}$ & 20.1 & 35.6 & 10.1 & 8.7 & 18.1 & 3.4 & 2.7 & 1.3 & 100 \\
\hline Erkek & 20.0 & 41.3 & 8.8 & 12.5 & 11.3 & 1.3 & 2.5 & 2.5 & 100 \\
\hline Toplam & 20.1 & 37.6 & 9.6 & 10.0 & 15.7 & 2.6 & 2.6 & 1.8 & 100 \\
\hline
\end{tabular}

Öğrencilerin Sütü Temin Ettikleri Yere Göre Dağılımı ve Tercih Ettikleri Süt Çeşitleri

Öğrencilerin süt ürünlerini temin ettikleri yerler sorulduğunda sırasıyla kı öğrencilerde $\% 83.3$ marketten, \%11.7 sokak sütçüsünden, $\% 2.5$ 'i bakkaldan ve $\% 2.5$ 'i pazardan aldiğ 1 ; erkek öğrencilerin \%77.6's1 marketten, \%13.4'ü sokak sütçüsünden, $\% 7.5$ 'i bakkaldan ve $\% 1.5$ 'i pazardan aldığ 1 tespit edilmiştir (Çizelge 8). Selçuk ve ark. (2003) yaptıkları çalışmada, öğrencilerin büyük k1smının (\%66.23) süt ürünlerini marketten temin ettiğgini bildirmişlerdir. Marketin öğrencilerin tercihinde ön plana çıkmasının sebebi; marketlerin şehir merkezinde istenen her noktada bulunabilmesi, çeşit zenginliği ve dolayısıyla istenilen her ürüne ulaşabilme ve bundan dolayı zaman kaybından tasarruf etme olabilir.

Çizelge 8. Öğrencilerin süt ürünlerini temin ettikleri yerler

\begin{tabular}{lccccccccccc}
\hline & \multicolumn{2}{c}{ Market } & \multicolumn{2}{c}{ Bakkal } & \multicolumn{2}{c}{ Pazar } & \multicolumn{2}{c}{ Diğer } & \multicolumn{2}{c}{ Toplam } \\
\cline { 2 - 11 } Cinsiyet & Sayı & \% & Sayı & \% & Sayı & \% & Sayı & \% & Sayı & \% \\
\hline K1z & 100 & 83.3 & 3 & 2.5 & 3 & 2.5 & 14 & 11.7 & 120 & 100 \\
Erkek & 52 & 77.6 & 5 & 7.5 & 1 & 1.5 & 9 & 13.4 & 67 & 100 \\
Toplam & 152 & 81.3 & 8 & 4.3 & 4 & 2.1 & 23 & 12.3 & 187 & 100 \\
\hline
\end{tabular}


Öğrencilere süt çeşidi tercihi sorulduğunda; kız öğrencilerin \%59.2'sinin pastörize sütü, \%27.5'i sterilize sütü ve \%13.3'ü de sokak sütünü tercih ettiği görülürken; erkek öğrencilerin ise \%53.7'si pastörize sütü, \%26.9'u sterilize sütü ve \%19.4'ü sokak sütünü tercih ettiği tespit edilmiştir (Çizelge
9). Karagözlü ve ark. (2005) yaptıkları çalışmada, öğrencilerin \%50.4'ünün pastörize sütü, \%40.7'sinin UHT sütü ve \%5.3'ünün sokak sütünü tercih ettiklerini bildirmişlerdir. Yapılan iki çalışmadan da öğrencilerin çoğunluğu pastörize sütü tercih ettiği görülmektedir.

Çizelge 9. Öğrencilerin tercih ettiği süt çeşidi

\begin{tabular}{lcccccccc}
\hline & \multicolumn{2}{c}{ Pastörize Süt } & \multicolumn{2}{c}{ Sterilize Süit } & \multicolumn{2}{c}{ Sokak Sütü } & \multicolumn{2}{c}{ Toplam } \\
\cline { 2 - 9 } Cinsiyet & Sayı & \% & Sayı & \% & Sayı & \% & Sayı & \% \\
\hline Kız & 71 & 59.2 & 33 & 27.5 & 16 & 13.3 & 120 & 100 \\
Erkek & 36 & 53.7 & 18 & 26.9 & 13 & 19.4 & 67 & 100 \\
Toplam & 107 & 57.2 & 51 & 27.3 & 29 & 15.5 & 187 & 100 \\
\hline
\end{tabular}

Öğrencilere "İçme sütü ambalajı olarak neleri tercih ediyorsunuz?" sorusu sorulduğunda alınan cevapların oranı Çizelge 10'da görülmektedir. Kız öğrencilerin \%57.1'i karton kutuyu, \%35.3'ü cam şişeyi, \%4.2'si plastik kutuyu ve \%3.4'ü de ambalajın süt satın almada bir tercih nedenleri olmadığını bildirirken; erkek öğrencilerin \%49.2'si karton kutuyu, \%41.5'i cam şişeyi, \%6.2'si ambalajın süt satın almada bir tercih nedenleri olmadığını ve \%3.1'i plastik kutuyu tercih ettiğini belirtmişlerdir. Ankete katılan öğrencilerin büyük bir kısmı cam şişede süt içmeyi tercih ettiklerini fakat maliyetinden dolayı karton kutuyu tercih etmek zorunda kaldıklarını da bildirmişlerdir.

Çizelge 10. Öğrencilerin tercih ettiği içme sütü ambalajı

\begin{tabular}{lccccccccccc}
\hline & \multicolumn{2}{c}{ Cam Şişe } & \multicolumn{2}{c}{ Karton Kutu } & \multicolumn{2}{c}{ Plastik } & \multicolumn{2}{c}{ Fikrim Yok } & \multicolumn{2}{c}{ Toplam } \\
\cline { 2 - 12 } Cinsiyet & Sayı & \% & Sayı & \% & Sayı & \% & Sayı & \% & Sayı & \% \\
\hline K1Z & 42 & 35.3 & 68 & 57.1 & 5 & 4.2 & 4 & 3.4 & 119 & 100 \\
Erkek & 27 & 41.5 & 32 & 49.2 & 2 & 3.1 & 4 & 6.2 & 65 & 100 \\
Toplam & 69 & 37.5 & 100 & 54.4 & 7 & 3.8 & 8 & 4.4 & 184 & 100 \\
\hline
\end{tabular}

Öğrencilerin Süt ve Süt Ürünlerini Tüketirken Dikkat Ettiği Unsurlar

Öğrencilerin süt ve süt ürünlerini tüketirken dikkat ettiği unsurlar sırasıyla; kız öğrencilerin \%32.3'ü son kullanma tarihine, \%24.2'si markaya, $\% 21.1$ 'i hijyene, \%14.3'ü yağ oranına, \%5.0'1 ürünün içeriğine ve \%3.1'i genel görünümüne; erkek öğrencilerin de \%32.1'i markaya, \%25.6's1 son kullanma tarihine, \%20.5'i yă oranına, \%19.2'si hijyene ve \%2.6'sının ürünün içeriğine dikkat ettiği tespit edilmiştir (Çizelge 11). Selçuk ve ark. (2003) yaptığı çalışmada, öğrencilerin $\% 47.80$ 'inin süt ürünleri alırken son kullanma tarihine dikkat ettiğini bildirmişlerdir. Uzunöz ve
Gülşen (2007) yaptıkları çalışmada, öğrencilerin süt satın alırken \%73.67'sinin hijyene, \%85.00'ının son kullanma tarihine, \%70.33'ünün ürünün markasına, $\% 22.33$ 'ünün genel görünümüne ve \%19.66'sının yağ oranına dikkat ettiğini bildirmişlerdir. Andiç ve ark. (2002) yaptıkları çalışmada, süt tüketen ailelerin \%52.9'unun sütün tazeliğine dikkat ettiğini, $\% 29.5$ 'inin hijyene, \%13.7'sinin fiyatına, \%3.1'inin bulunabilmesine ve $\% 1$ 'inin de markasına dikkat ettiklerini bildirmişlerdir. Yapılan iki çalışmadan da alınan sonuçlara göre; katılımcıların süt alırken değişik kriterlere dikkat ettiği görülmektedir. 
Gül PARA ve Ark.

Çizelge 11. Öğrencilerin süt ve süt ürünlerini tüketirken dikkat ettiği unsurlar

\begin{tabular}{lccccccccccccccc}
\hline & \multicolumn{3}{c}{ A } & \multicolumn{2}{c}{ B } & \multicolumn{2}{c}{ C } & \multicolumn{2}{c}{ D } & \multicolumn{2}{c}{ E } & \multicolumn{3}{c}{ F } & \multicolumn{2}{c}{ Toplam } \\
\cline { 2 - 14 } Cinsiyet & Sayı & \% & Sayı & \% & Sayı & \% & Sayı & \% & Sayı & \% & Sayı & \% & Sayı & \% \\
\hline Kız & 34 & 21.1 & 52 & 32.3 & 39 & 24.2 & 23 & 14.3 & 5 & 3.1 & 8 & 5.0 & 161 & 100 \\
Erkek & 15 & 19.2 & 20 & 25.6 & 25 & 32.1 & 16 & 20.5 & 0 & 0.0 & 2 & 2.6 & 78 & 100 \\
Toplam & 49 & 20.5 & 72 & 30.1 & 64 & 26.8 & 39 & 16.3 & 5 & 2.1 & 10 & 4.2 & 239 & 100 \\
\hline
\end{tabular}

A: Hijyen; B: Son kullanma tarihi; C: Marka; D: Yağ oranı; E: Genel görünüm; F: Ürünün içeriği.

Öğrencilere "İçme sütü alımında üretim ve son kullanma tarihine dikkat ediyor musunuz?" sorusu sorulduğunda alınan cevapların oranı Çizelge 12'de görülmektedir. Ankete katılan öğrencilerin büyük çoğunluğu (kı \%97.5, erkek \%86.2) üretim ve son kullanma tarihine dikkat ettiklerini belirtmişlerdir.
Selçuk ve ark. (2003) yaptıkları benzer bir çalışmada, öğrencilerin \%47.80'inin süt ürünlerini alırken tercih ettikleri markanın son kullanma tarihine dikkat ettiklerini tespit etmişlerdir. Yapılan iki çalışmadan da görüldüğü üzere; öğrencilerin içme sütü alımında son kullanma tarihine dikkat ettikleri görülmektedir.

Çizelge 12. İçme sütü alımında üretim ve son kullanma tarihine dikkat etme durumları

\begin{tabular}{lcccccc}
\hline & \multicolumn{2}{c}{ Evet } & \multicolumn{2}{c}{ Hayır } & \multicolumn{2}{c}{ Toplam } \\
\cline { 2 - 7 } Cinsiyet & Sayı & \% & Sayı & \% & Sayı & \% \\
\hline Kız & 116 & 97.5 & 3 & 2.5 & 119 & 100 \\
Erkek & 56 & 86.2 & 9 & 13.8 & 65 & 100 \\
Toplam & 172 & 93.5 & 12 & 6.5 & 184 & 100 \\
\hline
\end{tabular}

Öğrencilerin İçme Sütü Hakkındaki Genel Bilgileri

Ankete katılan öğrencilere içme sütünün besin değeri hakkındaki fikirleri sorulduğunda; kız öğrencilerin \%40.6'sının protein kaynağı olduğunu, \%37.5'i bilgi sahibi olmadığını, \%14.8'inin vitaminmineral kaynağı olduğunu, \%4.7'sinin ihtiyaç duyulan besin öğelerini içerdiğini ve \%2.3'ünün de enerji verdiğini belirtirken; erkek öğrencilerin \%40.3'ünün protein kaynağı olduğunu, \%40.3'ü bilgi sahibi olmadığını, \%11.9'unun vitamin-mineral kaynağı olduğunu, \%4.5'inin enerji verdiğini ve \%3.0'ssının da ihtiyaç duyulan besin öğelerini içerdiğini belirtmiştir
(Çizelge 13). Tarakçı ve ark. (2003) yaptıkları çalışmada, benzer bir soruya öğrencilerin \%19.11'i sütün protein içerdiği, \%3.86'sı şeker içerdiği,$\% 9.85$ ' $\mathrm{i}$ yağ içerdiği, \%16.02'si vitamin içerdiği, \%8.30'u enerji sağladığı, \%2.32'si bağışıklık kazandırdı̆̆ 1 , \%35.33'ü hepsini sağladığı şeklinde cevaplar almışlardır.

Bizim yaptığımız çalışmada da öğrencilerin sütün besleme değeri hakkında yetersiz bilgiye sahip olduğu ve bu konuda daha kapsamlı bilinçlendirme çalışmalarının yapılması gerektiği sonucuna ulaşıldı.

Çizelge 13. İçme sütünün besin değeri hakkındaki görüşler

\begin{tabular}{lcccccccccccc}
\hline & \multicolumn{3}{c}{ A } & \multicolumn{2}{c}{ B } & \multicolumn{2}{c}{ C } & \multicolumn{2}{c}{ D } & \multicolumn{2}{c}{ E } & \multicolumn{2}{c}{ Toplam } \\
\cline { 2 - 13 } Cinsiyet & Sayı & \% & Sayı & \% & Sayı & \% & Sayı & \% & Sayı & \% & Sayı & \% \\
\hline K1z & 52 & 40.6 & 3 & 2.3 & 19 & 14.8 & 6 & 4.7 & 48 & 37.5 & 128 & 100 \\
Erkek & 27 & 40.3 & 3 & 4.5 & 8 & 11.9 & 2 & 3.0 & 27 & 40.3 & 67 & 100 \\
Toplam & 79 & 40.5 & 6 & 3.1 & 27 & 13.9 & 8 & 4.1 & 75 & 38.5 & 195 & 100 \\
\hline
\end{tabular}

A: Protein kaynağı; B: Enerji verir; C: Vitamin-mineral kaynağı; D: İhtiyaç duyulan besin öğelerini içerir; E: Hiç biri. 
Ankete katılan öğrencilere süt fiyatları ile ilgili "Süt fiyatları hakkındaki fikriniz nedir?" sorusu sorulduğunda; kız öğrencilerin \%72.3'ünün uygun olduğunu, \%19.3'ünün pahalı olduğunu ve \%8.4'ünün ise ucuz olduğunu belirtirken; erkek öğrencilerin \%56.1'inin uygun olduğunu, \%37.9'unun pahalı olduğunu ve \%6.1' inin de ucuz olduğunu belirtmişlerdir (Çizelge 14). Tarakçı ve ark. (2003) yaptıkları çalışmada, öğrencilerin yarısının süt fiyatlarını diğer gıdalara oranla pahalı bulduğunu bildirmişlerdir.

Şimşek ve Açıkgöz (2011) yaptıkları çalışmada, öğrencilerin yarısından fazlasının (\%68.3) süt fiyatlarını normal bulduğunu tespit etmişlerdir. Yapılan çalışmalar ile bizim çalışma arasında farklılık gözlemlenmekte ve süt fiyatları hakkındaki düşüncenin zamanla değiştiği görülmektedir.

Çizelge 14. Öğrencilerin süt fiyatları hakkındaki düşünceleri

\begin{tabular}{lcccccccc}
\hline & \multicolumn{2}{c}{ Ucuz } & \multicolumn{2}{c}{ Uygun } & \multicolumn{2}{c}{ Pahalı } & \multicolumn{2}{c}{ Toplam } \\
\cline { 2 - 9 } Cinsiyet & Sayı & \% & Sayı & \% & Sayı & \% & Sayı & \% \\
\hline Kiz & 10 & 8.4 & 86 & 72.3 & 23 & 19.3 & 119 & 100 \\
Erkek & 4 & 6.1 & 37 & 56.1 & 25 & 37.9 & 66 & 100 \\
Toplam & 14 & 7.6 & 123 & 66.5 & 48 & 25.9 & 185 & 100 \\
\hline
\end{tabular}

Ankete katılan öğrencilere sterilize kutu sütlerinin uzun süre dayanmasının nedeni sorulduğunda verilen cevapların oranı Çizelge 15 'de görülmektedir. Kız öğrencilerin \%45.1'inin koruyucu katkı maddesi içerdiğini, \%34.4'ünün 1sıl işlem uygulandığını ve $\% 20.5$ 'inin fikir sahibi olmadığını belirtirken; erkek öğrencilerin \%48.5'i koruyucu katkı maddesi içerdiğini, \%30.3'ünün 1sıl işlem uygulandığını ve \%21.2'sinin fikir sahibi olmadığını belirtmişlerdir. Şimşek ve Açıkgöz (2011) yaptıkları çalışmada, öğrencilerin uzun ömürlü sütlerin uzun süre dayanmasının nedeni olarak \%41.6's1 koruyucu katk1 maddesi içermesi, \%36.8'i 1sıl işlem görmesi ve \%21.6's1 konu hakkında bilgi sahibi olmadıklarını tespit etmişlerdir. Yapılan iki çalışmadan da görüldüğü üzere; öğrencilerin sterilize kutu sütlerinin uzun süre dayanması için uygulanan yöntemler hakkında bir hayli eksik bilgiye sahip olduğunu göstermektedir.

Uzun ömürlü sütlerde katkı maddesi kullanıldığg düşüncesi doğru değildir, aksine bu sütlere sadece 1 sıl işlem uygulanmakta ve sütlerin daha uzun süre dayanması sağlanmaktadır. Türk gıda kodeksi ısıl işlem görmüş uzun ömürlü (UHT) içme sütünü şu şekilde tanımlamaktadır; çiğ sütün kimyasal, fiziksel ve duyusal özelliklerinde en az değişikliğe yol açarak bozulma yapabilen tüm mikroorganizmaların ve bunların sporlarının UHT (Ultra High Temperature) işlemi ile yok edilerek opak ambalaj veya paketleme ile opak hale getirilen ambalajlara aseptik koşullarda dolum yapılması ile elde edilen içme sütüdür (Anonim 2000).

Çizelge 15. Sterilize kutu sütlerin uzun süre dayanmasının nedenleri hakkındaki fikirleri

\begin{tabular}{lcccccccc}
\hline & \multicolumn{2}{c}{ Koruyucu Katkı Maddesi İçermesi } & \multicolumn{2}{c}{ Isıl İşlem } & Uygulanması & \multicolumn{2}{c}{ Bilmiyorum } & \multicolumn{2}{c}{ Toplam } \\
\cline { 2 - 8 } Cinsiyet & Sayı & \% & Sayı & \% & Sayı & \% & \multicolumn{1}{c}{ Sayı } & \% \\
\hline Kız & 55 & 45.1 & 42 & 34.4 & 25 & 20.5 & 122 & 100 \\
Erkek & 32 & 48.5 & 20 & 30.3 & 14 & 21.2 & 66 & 100 \\
Toplam & 87 & 46.3 & 62 & 33.0 & 39 & 20.7 & 188 & 100 \\
\hline
\end{tabular}


Ankete katılan öğrencilerin büyük çoğunluğu (\%82.1) toplumun süt içme konusunda yeterince teşvik edilmediğini belirtmişlerdir (Çizelge 16). Çetin (2003) yaptığı araştırmada, toplumun süt içme konusunda teşvik edilip edilmediği hakkındaki sorduğu soruya katılımcıların \%7.33'ü yeterli, \%73.83'ü yetersiz ve \%18.84'ü de fikir sahibi olmadıklarını bildirmişlerdir. Yapılan iki çalışmadan da görüldüğ ü gibi, toplumun süt içme konusunda yeterince teşvik edilmediği görülmektedir. $\mathrm{Bu}$ konuda çalışmaların daha kapsamlı devam ettirilmesi gerekmektedir.

Çizelge 16. Öğrencilerin, toplumun süt içme konusunda yeterince teşvik edilip edilmediğine yönelik görüşleri

\begin{tabular}{lcccccccc}
\hline & \multicolumn{2}{c}{ Yeterli } & \multicolumn{2}{c}{ Yetersiz } & \multicolumn{2}{c}{ Bilgim Yok } & \multicolumn{2}{c}{ Toplam } \\
\cline { 2 - 9 } Cinsiyet & Sayı & \% & Sayı & \% & Sayı & \% & Sayı & \% \\
\hline Kız & 21 & 14.3 & 123 & 83.7 & 3 & 2.0 & 147 & 100 \\
Erkek & 17 & 18.3 & 74 & 79.6 & 2 & 2.2 & 93 & 100 \\
Toplam & 38 & 15.8 & 197 & 82.1 & 5 & 2.1 & 240 & 100 \\
\hline
\end{tabular}

Ankete katılan öğrencilere "Toplumu süt içmeye teşvik etmede en etkili yol sizce nedir?" sorusu sorulduğunda; k1z öğrencilerin \%64.7'si radyotelevizyon, \%25.7'si diğer, \%7.5'i seminer ve \%2.1'i gazete-dergi cevabını verirken; erkek öğrencilerin $\% 81.7$ 'si radyo-televizyon, \%11.8'i diğer, \%4.3'ü seminer ve \%2.2'si de gazete-derginin daha etkili olacağını belirtmişlerdir (Çizelge 17).

Çizelge 17. Öğrencilerin, toplumu süt içmeye teşvik etmede en etkili yolun hangisi olduğuna yönelik düşünceleri

\begin{tabular}{lcccccccccc}
\hline & \multicolumn{2}{c}{ Gazete-Dergi } & \multicolumn{2}{c}{ Seminer } & \multicolumn{2}{c}{ Radyo-Tv } & \multicolumn{2}{c}{ Diğer } & \multicolumn{2}{c}{ Toplam } \\
\cline { 2 - 10 } Cinsiyet & Sayı & \% & Sayı & \% & Sayı & \% & Sayı & \% & Sayı & $\%$ \\
\hline Kız & 4 & 2.1 & 14 & 7.5 & 121 & 64.7 & 48 & 25.7 & 187 & 100 \\
Erkek & 2 & 2.2 & 4 & 4.3 & 76 & 81.7 & 11 & 11.8 & 93 & 100 \\
Toplam & 6 & 2.1 & 18 & 6.4 & 197 & 70.4 & 59 & 21.1 & 280 & 100 \\
\hline
\end{tabular}

Ankete katılan kız öğrencilerin \%87'si sütün şişmanlatmadığını, \%13'ü sütün şişmanlattığını; erkek öğrencilerin ise \%81.7'si sütün şişmanlatmadığını, $\% 18.3$ 'ü ise sütün şişmanlattığını belirtmişlerdir (Çizelge 18). Akbay ve Tiryaki (2007) yaptıkları çalışmada, katılımcıların \%19'unun sütün şişmanlattığını, \%50,36'sının ise şişmanlatmadı ̆̆ına inandıklarını tespit etmişlerdir. Erdal ve Tokgöz (2011) yaptıkları çalışmada, katılımcıların \% 33'ünün sütün şişmanlattığını, \%54'ünün ise böyle bir yargıyı taşımadığını bildirmişlerdir. Yapılan çalışmalarda alınan sonuçlara göre küçümsenemeyecek bir katılımcı oranının sütün şişmanlattığını söylediği tespit edilmiştir.

$\mathrm{Bu}$ düşüncenin yanlış olduğunu ve sütün şişmanlatmadığını aksine insan sağlı̆̆ı açısından faydalı olduğunu daha anlaşılır bir yöntemle anlatılması gerektiği görülmektedir.

Çizelge 18. Öğrencilerin sütün şişmanlatıp şişmanlatmadığı hakkındaki düşünceleri

\begin{tabular}{lcccccc}
\hline & \multicolumn{2}{c}{ Evet } & \multicolumn{3}{c}{ Hayır } & \multicolumn{2}{c}{ Toplam } \\
\cline { 2 - 7 } Cinsiyet & Sayı & \% & Sayı & \% & Sayı & \% \\
\hline K1z & 19 & 13.0 & 127 & 87.0 & 146 & 100 \\
Erkek & 17 & 18.3 & 76 & 81.7 & 93 & 100 \\
Toplam & 36 & 15.1 & 203 & 84.9 & 239 & 100 \\
\hline
\end{tabular}




\section{SONUÇ}

Erciyes üniversitesi öğrencilerinin süt tüketim alışkanlıklarının belirlenmesi üzerine yapılan bu çalışmada;

* Öğrencilerin haftada bir kez süt tükettiği,

* Süt tüketmeyen öğrencilerin süt tüketmeme nedenlerini bilmedikleri,

* Öğrencilerin sütü genellikle akşam öğününde tükettikleri,

* Günlük tükettikleri içme sütü tüketim miktarlarının 100-250 ml arasında olduğu,

* Sütü tercih etme nedenlerinin besleyicilik özelliği olduğu,

* İçeme sütü çeşidi olarak en çok soğuk sütü tercih ettikleri,

* Öğrencilerin büyük çoğunluğunun süt ürünlerini marketten temin ettikleri,

* İçme sütü ambalajı olarak karton kutuyu tercih ettikleri,

* Süt ürünlerini alırken dikkat ettikleri unsurun son kullanma tarihi olduğu,

* İçme sütünün besin içeriğinin protein ağırlıklı olduğunu düşündükleri,

* Öğrencilerin süt fiyatlarını uygun bulduğu,

* Toplum süt içme konusunda yeterince teşvik edilmediğini düşündükleri,

* Toplumu süt içmeye teşvik etmede en etkili yolun radyo-televizyon olduğu tespit edilmiştir.

Elde edilen sonuçlar incelendiğinde; öğrencilerin süt tüketiminin düzensiz olduğu ve bu alanda tedbirlerin alınması gerektiği görülmektedir. Sağlıklı ve dengeli

\section{KAYNAKLAR}

Akbay C, Tiryaki GY, 2007. Tüketicilerin ambalajlı ve açık süt tüketim alışkanlıklarının karşılaştırmalı olarak incelenmesi: Kahramanmaraş Örneği. KSÜ Fen ve Mühendislik Dergisi, 10(1): 89-96.

Altun B, Besler T, Ünal S, 2002. Ankara'da satılan sütlerin değerlendirilmesi. Sürekli Tıp Eğitimi Dergisi, 11 (2): 45-55.

Andiç S, Şahin K, Koç Ş, 2002. Van merkez ilçe kentsel alanda süt tüketimi. Yüzüncü Yıl Üniversitesi Tarım Bilimleri Dergisi, 12(2): 33-38.

Anonim, 2000. Türk Gıda Kodeksi. Çiğ Süt ve Isı1 İşlem Görmüş İçme Sütleri Tebliği. Tebliğ No: 2000/6.

Ayar A, Sert D, 2005. Toplum beslenmesinde süt ve süt ürünlerinin yeri ve önemi. Gıda ve Yem Bilimi Teknolojisi Dergisi, 7(1): $1-5$.

Çetin C, 2003. İstanbul ilinde içme sütü tüketim alışkanlıkları ve bu alışkanlıkları etkileyen faktörlerin belirlenmesi üzerine bir araştırma. http://dspace.trakya.edu.tr:8080/jspui/handle/1/70. (Erişim Tarihi: 20 Eylül, 2017).

Çetinkaya A, 2010. Kafkas üniversitesi öğrencilerinin içme sütü ve süt ürünlerini tüketim alışkanlıklarının belirlenmesi. Atatürk Üniversitesi Veteriner Bilimleri Dergisi, 5(2): 73-84.

Erdal G, Tokgöz K, 2011. Tüketicilerin ambalajlı ve açık süt tüketim tercihlerini etkileyen faktörler: Erzincan ili örneği. Karamanoğlu Mehmetbey Üniversitesi Sosyal Ve Ekonomik Araştırmalar Dergisi, 2011(1): 111-115.

Kahraman EM, 2016. İçme sütü tüketim alışkanlıkları ve marka seçiciliğinde etkili faktörlerin analizi: izmir ili örneği. Ege Üniversitesi Fen Bilimleri Enstitüsü, (Basılmamış) Doktora Tezi, 166s. beslenmede sütün öneminin vurgulanması amacıyla eğitim faaliyetleri düzenlenmesi ve bilinçlendirme çalışmalarına daha fazla önem verilmesi gerektiği söylenebilir.

Karagözlü N, Karagözlü C, Karaca S, Eren S, 2005. Üniversite öğrencilerinde süt ve ürünleri tüketim alışkanlıkları ve beslenme bilinçleri üzerine bir araştırma. Celal Bayar Üniversitesi Fen Bilimleri Dergisi, 1(2): 101-108.

Mazıcıŏlu MM, Öztürk A, 2003. Üniversite 3 ve 4. sınıf öğrencilerinde beslenme alışkanlıkları ve bunu etkileyen faktörler. Erciyes Tıp Dergisi (Erciyes Medical Journal), 25(4): 172-178.

Onurlubaş E, Doğan HG, Demirkıran S, 2015. Üniversite öğrencilerinin beslenme alışkanlıkları. Gaziosman Paşa Üniversitesi Ziraat Fakültesi Dergisi, 32(3): 61-69.

Selçuk Ş, Tarakçı Z, Şahin K, Coşkun H, 2003. Yüzüncü Yıl Üniversitesi lisans öğrencilerinin süt ürünleri tüketim alışkanlıkları. Yüzüncü Yıl Üniversitesi Tarım Bilimleri Dergisi, 13(1): 23-31.

Şimşek B, Açıkgöz İ, 2011. Süleyman Demirel Üniversitesi öğrencilerinin içme sütü tüketim alışkanlıklarının belirlenmesi. Yüzüncü Yıl Üniversitesi Tarım Bilimleri Dergisi, 21(1): 12-18.

Tarakçı Z, Selçuk Ş, Şahin K, Coşkun H, 2003. Üniversite öğrencilerinin içme sütü tüketim alışkanlıkları üzerine bir araştırma. Yüzüncü Yıl Üniversitesi Tarım Bilimleri Dergisi, 13(1): 15-21.

Uzunöz M, Gülşen M, 2007. Üniversite öğrencilerinin süt ve süt ürünleri tüketim alışkanlıklarının belirlenmesi. Gıda Teknolojileri Elektronik Dergisi, 3: 15-21. 